University of Warwick institutional repository: http://go.warwick.ac.uk/wrap This paper is made available online in accordance with publisher policies. Please scroll down to view the document itself. Please refer to the repository record for this item and our policy information available from the repository home page for further information.

To see the final version of this paper please visit the publisher's website. Access to the published version may require a subscription.

Author(s): Pratt Nicola

Article Title: Identity, Culture and Democratization: The Case of Egypt Year of publication: 2005

Link to published version: http://dx.doi.org/10.1080/07393140500030832

Publisher statement: None 


\section{Identity, Culture and Democratization: The Case of Egypt $^{1}$}

\section{Introduction}

This article seeks to present an alternative approach to understanding the failure of democratization in the Arab world by locating the problem of democracy-building within the logic of national identity and culture construction. ${ }^{2}$ Taking Egypt as a case study, I examine a series of events surrounding a human rights report about police brutality in Egypt to illustrate how the struggle to maintain Egyptian national identity in the context of globalization and ever-increasing transnational linkages acts to undermine attempts to promote the civil and political freedoms necessary for the practice of democracy. As one Egyptian civil society activist writes:

Why should Egyptians quarrel with each other about their identity? ...

Whenever there is an acute crisis regarding Egypt's political direction and its socio-political set-up, it turns into a search for something broader and deeper-a 'soul' and a 'fabric'. 3

This paper argues that, in the course of searching for an 'authentic' Egyptian identity, uncorrupted by Western influences, a critical mass of Egyptian civil society participates in producing a political consensus that excludes the possibility of fluidity and heterogeneity, thereby contributing to creating a climate in which civil and political freedoms may be legitimately sacrificed in the name of national unity and security. This is despite attempts by some Egyptian activists to challenge dominant conceptions of national identity and culture in order to open up democratic spaces.

\footnotetext{
${ }^{1}$ This article is based on fieldwork conducted as part of my doctoral project, 1998-2001, and funded by the UK Economic and Social Research Council. I would like to thank my dissertation adviser, Dr Salwa Ismail at the University of Exeter, for her support and suggestions throughout this project. In addition, I thank the two anonymous reviewers of this article for their useful suggestions.

${ }^{2}$ In addition to 'culturalist' approaches, the failure of democratization or the maintenance of authoritarianism has been attributed to political economy factors, such as the rentier state paradigm, the interplay between state formation and the international political economy and the lack of independence of civil society from the state. See, respectively, Hazem Beblawi and Giacomo Luciani, eds. The Rentier State (London: Croom Helm, 1987), Simon Bromley, Rethinking Middle East Politics (Oxford: Polity Press, 1994) and Eva Bellin, Stalled Democracy: Capital, Labor, and the Paradox of StateSponsored Development (Ithaca \& London: Cornell University Press, 2002). The purpose of this article is not to critique these approaches but rather to 'bring culture back in' without reifying it.

${ }^{3}$ Ahmed Abdulla, “The Egyptian National Identity and Pan-Arabism Variations and Generations,” in Roel Meijer, ed. Cosmopolitanism, Identity and Authenticity in the Middle East (Richmond: Curzon, 1999), pp. 172-73.
} 
The first part of the paper critically reviews some of the uses of the concept of culture in explaining Arab politics. Rather than rejecting the explanatory value of culture in the study of politics, I draw upon a sociological conception of culture that avoids the problems of essentialization associated with previous usages of the term. I then combine concepts from the writings of Antonio Gramsci and postcolonial theorists, such as Edward Said, to explore the links between culture and politics—in particular, the way in which political power is operationalized through cultural processes and the role of civil society in reproducing or challenging culture. The second part applies this framework to a case study of the events surrounding an Egyptian human rights report about police brutality to illustrate how the process of national identity and culture formation undermines democratization. ${ }^{4}$ Finally, I draw together the main arguments and their implications for understanding democratization in the conclusion.

\section{Identity, culture and politics}

'Culture' as an explanation for the nature of politics in the Arab world—in particular the failure of democratization —has obtained a bad name. This is unsurprising in light of the way the concept has been used. There has been an overwhelming tendency to present Arab/Muslim culture as ahistorical and essentialized. Authors such as Elie Kedourie and Bernard Lewis, writing within the tradition of orientalism, have argued that Arab/Muslim culture is incompatible with democracy because concepts associated with democracy, such as representative government, freedom and the separation of religion from state, are unknown within Islam and the Arab political tradition. ${ }^{5}$ In "The Clash of Civilisations," Samuel Huntington employs the concept of essentialized cultural difference between a liberal, democratic, secular 'West' versus the 'Rest,' including the Islamic world, where Western values possess little cultural resonance, to describe the emerging pattern of global politics in the post-Cold War context. ${ }^{6}$

Not only is this approach questionable in terms of its static conceptualization of culture, but also because of its lack of empirical vigor. Rather than deriving Arab attitudes to politics from the study of current politics and society, writers have claimed that it is possible to know Arab political culture from

\footnotetext{
${ }^{4}$ That is, the aim of the article is to produce a case study of the events surrounding the report of events in al-Kushah and not to present a case study of the actual events that occurred in al-Kushah.

${ }^{5}$ Elie Kedourie, Democracy and Arab Political Culture (London: Frank Cass, 1994); Bernard Lewis, “Islam and Liberal Democracy,” Atlantic Monthly 271: 2 (February 1993), pp. 89-98.

${ }^{6}$ Samuel Huntington, “The Clash of Civilizations?” Foreign Affairs 72 (1993), pp. 22-49.
} 
readings of religious texts and Arab history. A relationship of causation is established (that is, the lack of democracy is explained by the existence of Arab/Islamic culture) without presenting any evidence to demonstrate such a link. As Lisa Anderson argues, it is equally possible that the lack of democracy is caused by low economic development rates or the absence of full national sovereignty, yet this is never argued by those who promote a political culture approach. ${ }^{7}$ Moreover, even a cursory study of politics within Arab/Islamic countries demonstrates the degree of conflict within these societies over such issues as human rights, the role of women in the public sphere and the nature of citizenship. Rather than being culturally homogenous blocs of opposition to so-called Western values, Arab/Islamic countries contain a variety of individuals and groups who are actively involved in promoting democracy and human rights (as the case study below will demonstrate).

Outside of Middle East politics, the political culture concept has also been subject to criticisms. The predominant approach is encapsulated by Almond and Verba's work on 'civic culture,' in which they argue that democracy is the outcome of citizens possessing the right mix of attitudes towards the political system. ${ }^{8}$ More recently, Putnam's work on social capital has argued that democracy is rooted in the level of associational life and existence of norms of trust and cooperation. A decline in these factors has led to a decline in the quality of democracy in the United States. ${ }^{9}$ These conclusions are based on the findings of survey data of individuals' attitudes towards the political system and empirical observation of the number of people joining associations.

Such an approach is more rigorous than the methods used by writers within the orientalist tradition. However, the establishment of a correlation between certain cultural attributes and habits, on the one hand, and democracy on the other, does not establish a relationship of causation. It is possible that people's attitudes could be a product of the nature of the political system, rather than shaping it. Given these problems, in what way can a study of culture, as opposed to a study of political economy or political institutions, contribute to our understanding of politics and, in particular, democratization? What is the case for 'bringing it back in'? ${ }^{10}$ I argue that political scientists cannot ignore culture-

\footnotetext{
${ }^{7}$ Lisa Anderson, "Democracy in the Arab World: A Critique of the Political Culture Approach,” in Rex Brynan et al, eds. Political Liberalization \& Democratization in the Arab World: Theoretical

Perspectives (Boulder, Colorado: Lynne Rienner, 1995), p. 89.

${ }^{8}$ Gabriel Almond \& Sidney Verba, The Civic Culture: Political Attitudes and Democracy in Five Nations (Princeton, NJ: Princeton University Press, 1963).

${ }^{9}$ Robert Putnam, Bowling Alone: The Collapse and Revival of American Community (New York: Simon \& Schuster, 2000).

${ }^{10}$ Michael Hudson, "The Political Culture Approach to Arab Democratization: The Case for Bringing It Back in, Carefully,” in Rex Brynan et al, eds. Political Liberalization and Democratization in the Arab World: Theoretical Perspectives (Boulder, Colorado: Lynne Rienner, 1995), pp. 61-76.
} 
although they do need to reconsider its conceptualization. Without recourse to the concept of culture, politics becomes reduced to an effect of economics, institutions or externalities. ${ }^{11}$ Yet politics constitutes a form of social interaction and, therefore, cannot be divorced from the many aspects constituting social life. A feature of those inherited circumstances is the culture through which individuals live their lives and attempt to change their lives.

Lisa Wedeen argues that an anthropological conceptualization of culture (as 'semiotic practices') demonstrates how cultural practices produce political effects and give meaning to these. ${ }^{12}$ Wedeen's approach avoids the pitfalls discussed above by theorizing culture as a social practice, rather than a reified system of beliefs, values and personality traits. Culture is the practice of 'meaning-making' in which actors make the world in which they live intelligible. ${ }^{13}$ These meanings do not exist only in people's heads but are realized in the ways that people live their lives—in the choices that they make and in their everyday behavior. ${ }^{14}$

Nevertheless, people do not participate in this meaning-making in a vacuum. Culture also precedes cultural practices, thereby influencing and constraining how actors engage in the reproduction of culture:

So the existing cultural patterns form a sort of historical reservoir-a preconstituted 'field of the possibles' — which groups take up, transform, develop. Each group makes something of its starting conditions—and through this 'making', through this practice, culture is reproduced and transmitted. But this practice only takes place within the given field of possibilities and constraints. ${ }^{15}$

In other words, culture, as a social practice, is not something that individuals possess. Rather, it is a social process in which individuals participate, in the context of changing historical conditions.

As an 'historical reservoir,' culture is an important factor in shaping identity. However, this identity is not static. Identity, like culture, is understood here as fluid and historically-constituted:

\footnotetext{
${ }^{11}$ ibid: 62.

${ }^{12}$ Lisa Wedeen, “Conceptualizing Culture: Possibilities for Political Science,” American Political Science Review 96: 4 (2002), p. 714.

${ }^{13}$ John Clarke et al, "Subcultures, Cultures and Class," in Stuart Hall \& Tony Jefferson, eds. Resistance through Rituals: Youth Subcultures in Post-war Britain (London: Hutchinson, 1976), pp. 9-74; Lisa Wedeen, Ambiguities of Domination: Politics, Rhetoric, and Symbols in Contemporary Syria (Chicago: University of Chicago Press, 1999).

${ }^{14}$ Ibid.

${ }^{15}$ Clarke et al, "Subcultures, Cultures and Class,” p. 11.
} 
Cultural identity ... is a matter of 'becoming' as well as 'being'. ...

Far from being eternally fixed in some essentialised past, they

[identities] are subject to the continuous 'play' of history, culture and

power ... identities are the names we give to the different ways we are

positioned by, and position ourselves within, the narratives of the

past. ${ }^{16}$

Culture and identity represent important concepts within the study of political science because they influence how individuals and groups engage with the world—including the world of politics. The processes of cultural construction and identification "bridge agency and structure, are multiple and sometimes contradictory, and can be understood as strategies". ${ }^{17}$ Identities—whether based on class, gender, religion, nationality or some other social/cultural marker—play a role in building social movements and 'framing contention'. ${ }^{18}$ Moreover, the realm of culture and identity is often the object of contestation for social movements. For example, one of the distinguishing features of the political Islamist movements in the Arab world is their emphasis on promoting an 'Islamic culture. ${ }^{19}$ In Egypt, Islamist activists have imposed gender segregation and censorship on university campuses, burnt video rental shops and undertook the policing of wedding parties to prevent the consumption of alcohol. ${ }^{20}$ They have also mobilized street protests against cultural productions that they deem heretical. ${ }^{21}$ Conversely, the Egyptian state has also attempted to counter Islamist opposition through producing its own version of Islamic culture, through magazines, newspapers and television programs. ${ }^{22}$ The

${ }^{16}$ Stuart Hall, "Cultural Identity and Diaspora," in J. Rutherford, ed. Identity: Community, Culture, Difference (London: Lawrence \& Wishart, 1990) reproduced in Patrick Williams \& Laura Chrisman, eds. Colonial Discourse and Post-colonial Theory: A Reader (New York: Columbia University Press, 1994), p. 394.

${ }^{17}$ V. Spike Peterson, “Sexing Political Identities/Nationalism as Heterosexism”, in Sita RanchodNilsson \& Mary Ann Tétreault, eds. Women, States, and Nationalism (London \& New York, Routledge, 2000), p. 57.

${ }^{18}$ Sidney Tarrow, Power in Movement (Cambridge: Cambridge University Press, 1998), p. 119.

${ }^{19}$ Larbi Sadiki, The Search for Arab Democracy: Discourses and Counter-discourses (New York: Columbia University Press, 2004), pp. 322-23.

${ }^{20}$ Nazih Ayubi, Political Islam: Religion and Politics in the Arab World (London: Routledge, 1991);

Salwa Ismail, “Religious ‘Orthodoxy’ as Public Morality: the State, Islamism and Cultural Politics in

Egypt,” Critique (spring, 1999), pp. 25-47.

${ }^{21}$ For example, in 2000, Islamists mobilized significant opposition to a novel ('A Banquet for Seaweed' by Syrian novelist, Haydar Haydar), which was published by the state-owned General Organization for Cultural Palaces. This led to the editor and managing editor of the book series being officially charged with blasphemy. Samia Mehrez, "Take Them out of the Ball Game,” Middle East Report 219 (summer, 2001) http://www.merip.org/mer/mer219/219_mehrez.html

${ }^{22}$ Ismail, ““'Religious ‘Orthodoxy’ as Public Morality.” 
importance of dominating the cultural sphere in order to exercise political power may be signaled by the huge amount of resources dedicated to promoting the leadership cult of the former Syrian President Hafiz al-Asad. Wedeen argues that the state's promotion of this cult is essential in producing political compliance amongst citizens. ${ }^{23}$

Culture is not only a resource in the process of identification but also one of the means of structuring the social relationships that underpin hierarchies of power-between state and civil society, men and women, different classes and other social groups. These hierarchies of power provide the infrastructure for maintaining authoritarianism and preventing democratization. The role of culture in structuring politics is theorized by Antonio Gramsci. For Gramsci, the dominant class exercise power not only through mechanisms of coercion, such as the police, military and the legal system, but also through winning consent by a variety of non-coercive means, including political, economic/material and cultural. ${ }^{24}$ The exercise of power through consent backed by coercion is termed 'hegemony'. Consent is diffused through civil society—-that is, "the ensemble of organisms commonly called 'private',,25 such as, religion, trade unions and the education system. ${ }^{26}$ Civil society, as both institutions and an arena of moral and cultural production, play a role in reproducing and maintaining hegemony. Civil society represents the 'trench systems' of the state—-the terrain upon which the battle for hearts and minds is conducted. ${ }^{27}$

In order to be successful, hegemony must appear to be in the interests of the majority of society and not only in those of the dominant class. ${ }^{28}$ A widespread belief in the validity of the existing hegemony is essential because it relies on the participation of ordinary people in its continued reproduction. Like culture and identity, hegemony represents an historical process: "It has continually to be renewed, recreated, defended, and altered, challenged by pressures not at all its own”. 29

Nationalism represents one of the most potent sources of identification in the modern period. The construction of a national identity and culture represents a powerful means for national elites to unite

\footnotetext{
${ }^{23}$ Wedeen, Ambiguities of Domination.

${ }^{24}$ Antonio Gramsci, Selections from the Prison Notebooks, tran. \& ed. by Quinton Hoare \& Geoffrey Nowell-Smith (London: Lawrence \& Wishart, 1971), p. 258. Economic/material means could include reforming the tax system in favour of certain groups, political means could refer to the parliamentary system, which fosters the illusion of self-government on the part of the population. Terry Eagleton, Ideology: An Introduction (London: Verso, 1991), p. 112.

${ }^{25}$ Gramsci, Selections, p. 12.

${ }^{26}$ Ibid, p. 56 n. 5.

${ }^{27}$ Joseph Femia, “Civil Society and the Marxist Tradition,” in Sudipta Kaviraj \& Sunil Khilnani, eds. Civil Society: History and Possibilities (Cambridge: Cambridge University Press, 2001), p. 140.

${ }^{28}$ Gramsci, $\underline{\text { Selections, p. } 161 .}$

${ }^{29}$ Raymond Williams, Marxism and Literature (Oxford: OUP, 1977), p. 112.
} 
citizens within a territorially-bound political community and to win consent for their political leadership. The discourse of nationalism is constituted through the construction of an identity and culture that is exclusive and different from those of other nations. However, this is not a top-down project for it relies on citizens of the nation-state to actively participate in the reproduction of national traditions, the telling of national history, the performance of national rituals, the celebration of national heroes, and the commemoration of national anniversaries. ${ }^{30}$ These practices represent a means of 'imagining the nation' as a unified, political community but also constitute some of the ways by which civil society contributes to the maintenance of hegemony.

Culture is not only a means of legitimizing the political status quo but also of challenging it. Bhahba argues that the 'performative' process of national culture gives space to those at the margins of the nation, such as women, workers and ethnic/religious minorities, to intervene in the reproduction of the dominant culture and to challenge it with their own 'narratives. ${ }^{31}$ For Gramsci, civil society is not only the terrain upon which the dominant class secures consent for its rule. It is also the sphere in which dominated social groups may organize their opposition and construct an alternative (or 'counter') hegemony. ${ }^{32}$ The importance of engaging in the realm of culture as a means of challenging the dominant political order has been understood by diverse social movements throughout history. As noted above, the Islamist movement in Egypt is active in attempting to shape cultural practices. In the 1960s and 1970s, the student movement and youth counter-cultures, such as the hippies, represented dissent from the political and cultural institutions of Western European and North American societies. ${ }^{33}$

The nature of hegemony — the type of mechanisms of consent and coercion employed—is determined by the economic, social and cultural environment within which it is produced. For Egypt and other countries once colonized, the postcolonial experience represents a significant historical moment shaping the production and reproduction of hegemony in the post-independence period. The 'postcolonial' is a highly contested term. ${ }^{34}$ However, here I use it to signify "the spaces where many men and women have to intervene in structures worked through by colonialism, as well as earlier and

\footnotetext{
${ }^{30}$ Homi Bhabha, The Location of Culture (London: Routledge, 1994), p. 145.

${ }^{31}$ Ibid.

${ }^{32}$ David Forgacs, ed. The Antonio Gramsci Reader: Selected Writings 1916-1935 (London: Lawrence \& Wishart, 1999), p. 420.

${ }^{33}$ Clarke et al, "Subcultures, Cultures and Class," p. 62.

${ }^{34}$ For example, Anne McClintock, "The Angel of Progress: Pitfalls of the Term 'Post-colonialism', , Social Text (spring, 1992), pp. 1-15; Vijay Mishra\& Bob Hodge, "What is Post(-)colonialism?”

Textual Practice 5: 3 (1991), pp. 399-414.
} 
later histories of domination." 35 The experience of colonialism represents a significant narrative of the past in relation to which men and women position themselves; a historical reservoir for the reproduction of hegemony and the construction of counter-hegemony in the post-independence period. An integral part of the experience of colonial domination was the discourse constructed by Europeans about the peoples they colonized. Edward Said has characterized this discourse as 'orientalism': “a Western style for dominating, restructuring, and having authority over the Orient., ${ }^{36}$ In other words, the discourse of colonialism represented one of the mechanisms by which Europe dominated its colonies, as well as being a framework justifying that domination. The 'Orient' existed as an inferior 'Other' to Europe and this inferiority was rooted in the Orient's "ineradicable distinction” from Europe. ${ }^{37}$

Understanding that European domination was exercised through the derogatory and essentialized representations of the peoples of the 'Orient' (not only with regard to the Middle East but throughout the colonized world), anti-colonial movements sought to construct their own identities as a means of liberation from colonialism. In the Arab region, competing bases for identity emerged based on secular nationalism or ethnic/religious identities. In Egypt, the liberal Wafd was pivotal in leading a movement for national independence from the British that claimed that, "Egypt is for the Egyptians and religion is for God”. From the 1930s onwards, a radicalization of opposition to British rule and the failure of indigenous elites to achieve independence produced more populist-nativist movements, such as Misr al-Fatah and the Muslim Brotherhood. ${ }^{38}$

Obviously, each of these groups had a different ideological outlook, different visions for the future of their societies and different concepts of what/whom constituted the nation. Nevertheless, on the whole they shared common themes. ${ }^{39}$ As part of their resistance to European domination, they sought to reverse the representations of the colonized by the colonizer. Where the 'Orient' has been portrayed by Europeans as ahistoric, uncivilized, unscientific, and sexually decadent (in contradistinction to European culture, which has been represented as the pinnacle of civilization), those movements seeking to challenge European domination have generally portrayed their peoples as embodying an essence of

\footnotetext{
${ }^{35}$ Ania Loomba, “Overworlding the 'Third World',” Oxford Literary Review 13 (1991), p. 191.

${ }^{36}$ Edward Said, Orientalism (London: Penguin, 1978), p. 3.

${ }^{37}$ Ibid, p. 42.

${ }^{38}$ Israel Gershoni, "Rethinking the Formation of Arab Nationalism in the Middle East, 1920-1945: Old and New Narratives", in J. Jankowski \& I. Gershoni (eds.), Rethinking Nationalism in the Arab Middle East (New York: Columbia University Press, 1997), pp. 17-18.

${ }^{39}$ Selma Botman, The Rise of Egyptian Communism, 1939-1970 (New York: Syracuse University Press, 1988), pp. 20-21.
} 
spirituality and moral purity not possessed by Europeans. ${ }^{40}$ In Egypt, all anti-colonial trends were engaged in debates about the 'proper' role of women, the need to ban decadent European influences, such as alcohol, and the role of Islam in public life. ${ }^{41}$ These different ideological/cultural trendssecular, Islamist and cultural-nationalist—are still represented amongst different political groups in Egypt today and they still engage in debates that seek to define Egyptian culture and identity. ${ }^{42}$ Yet, the construction of essentialized, cultural differences between the colonizers and the colonized was and remains central to the logic of identity construction in relation to all these different trends. ${ }^{43}$ In addition to sharing common themes, the discourses of these various movements may be considered similar in their aims in that they represented a strategy, employed by other politically marginalized peoples, of challenging the hegemonic cultural representations through the construction of a 'countercultural' discourse, as a means to "transmute marginality into identity." 44 In so doing, "The constructed 'traditional' culture becomes a means [...] to articulate personal autonomy with collective empowerment ...."45

Yet, the reversing of orientalist stereotypes as a strategy for resisting colonialism reproduces the logic of difference rooted in the binary division created by the colonizer between the 'Occident' and the 'Orient.' ${ }^{46}$ This logic necessarily entails the construction of 'essences' that deny difference within nations. In order to maintain a fixed, monolithic identity, nationalist discourse must construct boundaries, which are carefully policed to maintain unity in the face of the 'Other.' Foreign influences over national culture and identity are seen as a means for the West to undermine the nation. The policing of the nation's boundaries are conducted both through the construction of consent for the hegemonic culture backed by coercive mechanisms.

\footnotetext{
${ }^{40}$ Partha Chatterjee, The Nation and Its Fragments: Colonial and Postcolonial Histories (Princeton: Princeton University Press, 1993).

${ }^{41}$ For example, see P.J. Vatikiotis, The History of Modern Egypt (London: Weidenfeld \& Nicolson,1991), pp. 328-330; M.E. Yapp, The Near East Since the First World War: A History to 1995 (Harlow, Essex: Longman,1996), p. 64; Margot Badran, Feminists, Islam, and Nation: Gender and the Making of Modern Egypt (Princeton, N.J.: Princeton University Press, 1995); and Mervat Hatem, "Toward the Development of Post-Islamist and Post-Nationalist Feminist Discourses in the Middle East”, in Judith E. Tucker (ed.) Arab Women: Old Boundaries, New Frontiers (Bloomington \& Indiana: Indiana University Press, 1993), pp. 38-42.

${ }^{42}$ The case of the Islamist mobilization against the publishing of the Haydar Haydar novel by a state owned publishing house illustrates this tendency.

${ }^{43}$ William E. Connolly, Identity/Difference: Democratic Negotiations of Political Paradox (Ithaca \& London: Cornell University Press, 1991), p. 9; Chatterjee, The Nation and Its Fragments.

${ }^{44}$ Larbi Sadiki, The Search for Arab Democracy: Discourses and Counter-discourses (New York: Columbia University Press, 2004), p. 120.

${ }^{45}$ Paul Gilroy, There Ain’t No Black in the Union Jack (London: Hutchinson, 1987), p. 248.

${ }^{46}$ Sadiki, The Search for Arab Democracy, p. 111.
} 
Consequently, the process of identity construction as a means of resistance to the West contains an anti-democratic logic. Cultural practices that seek to reproduce an essentialized and homogeneous national identity in contradistinction to the West necessarily entail the suppression of internal difference within the nation. For example, women are often represented as the repository of the moral values and cultural essence that distinguishes the nation from other nations. ${ }^{47}$ This has led to the introduction of official and/or informal measures to regulate women's sexuality, the way they dress and the roles they may adopt within the public sphere in order to protect the essence of the nation from foreign influences. ${ }^{48}$ In general, those who fail to conform to the hegemonic culture by affirming alternative identities or engaging in alternative cultural practices, such as those based on their ethnicity, religion or sexuality are often perceived as a threat to the national 'way of life' and as a conduit for foreign influence in domestic affairs. Moreover, those who become directly associated with the West, for example, as human rights activists part of a wider, transnational movement, are also perceived as a threat to the nation. Consequently, in all these cases, it becomes legitimate to not address their claims or even to violate their rights, as the case study below will demonstrate. ${ }^{49}$

\section{Civil society, the nation and democratization: the case of Egypt}

The following case study demonstrates how the process of reproducing a fixed national identity in postcolonial Egypt acts to delegitimize the civil and political freedoms, and those who seek to promote them, necessary for the practice of democracy. Civil society constituted a key player in this process of reproducing national identity. The case study addresses a particular series of events that occurred between August 1998 and December 1998. In August 1998, the Egyptian Organization for Human Rights (EOHR) wrote a report about a case of mass police brutality in the predominantly Coptic Christian village of al-Kushah, in Upper Egypt. The EOHR report and the international reaction to the events in al-Kushah sparked an intense debate in the Egyptian media over the role of Egyptian human rights NGOs in publicizing human rights violations. The debate centered not upon the 'facts' of the EOHR report but rather upon the need to protect Egyptian national sovereignty from Western

\footnotetext{
${ }^{47}$ Deniz Kandiyoti, “Identity and its Discontents: Women and the Nation,” Millenium 20: 3 (1991), pp. 429-43; Chatterjee, The Nation and Its Fragments.

${ }^{48}$ Nira Yuval-Davis \& Floya Anthias, eds. Women-Nation-State (Basingstoke and London: Macmillan, 1989).

${ }^{49}$ The concept of rights used here refers to basic human rights contained within the Universal Declaration, such as, freedom from torture or cruel, inhuman and degrading treatment; freedom from discrimination based on gender, religion or any other social marker; freedom of association; and freedom of speech.
} 
influence. This was far from academic since it actually led to—or at least provided a justification for— the arrest of the EOHR secretary-general.

This case study is illustrative of the relationship between national identity production and democratization and this dialectic can be seen to have played out in other cases, such as the arrest, trial and imprisonment (in 2000/2001) of prominent Egyptian civil society activist Saad Eddin Ibrahim and his colleagues and the government's justification for amending the law regulating Egyptian NGOs. ${ }^{50}$ In these cases, Egyptian human rights NGOs are represented (by the government as well as other members of civil society) as a potential threat to Egyptian sovereignty because of their acceptance of grants from organizations and governments based in the geographic West. It is claimed that the West seeks to impose its values through these links and, thereby, undermines Egyptian culture, which is the basis for national sovereignty. Egyptian human rights groups, as well as other NGOs, are reliant upon foreign grants to finance their operations due to the limited ability to collect sufficient funds domestically. Despite the fact that NGOs engaged in welfare/developmental activities also receive grants from abroad, it is principally human rights NGOs that are the target of criticism in this regard and this is no doubt due to the fact that human rights work entails high profile challenges to the Egyptian authorities. ${ }^{51}$ It is significant that in the majority of cases (including this one), what is at stake is not proving the falsity of allegations of human rights abuses, but rather proving links with foreign organizations, which, within the logic of the nationalist discourse, thereby discredits any claims made by human rights groups.

In August 1998, the EOHR received complaints of mass police brutality in an Upper Egyptian village called al-Kushah, in the governorate of Suhag, approximately 550 kilometers south of Cairo. Following a fact-finding mission, the organization published a report stating that over five hundred men, women and even children had been arbitrarily detained, tortured or subjected to maltreatment by the police in

\footnotetext{
${ }^{50}$ The trial of Saad Eddin Ibrahim was widely reported in both the Egyptian and US media. For a selection of some of the newspaper articles written on the subject, see, the "Free Saadeddin Ibrahim" website http://groups.yahoo.com/group/free_saadeddin_ibrahim. Ibrahim was acquitted and released in May 2003. Regarding the amendments to the law regulating NGOs, see Nicola Pratt, "Bringing Politics Back In: Examining the Link between Globalization and Democratization”, Review of International Political Economy 11:2, May 2004, pp. 311-336.

${ }^{51}$ Arguments are sometimes made that foreign funding undermines the independence of NGOs, leads to internal corruption/rent-seeking behaviour amongst individuals within these organizations and leads NGOs to follow donor agendas (for example, see various authors in the edition of Middle East Report dedicated to the issue of NGOs in the Arab world, no. 214, Spring 2000). In the course of conducting my own research of Egyptian human rights NGOs, I did not find evidence that there is necessarily a link between accepting foreign funding and any of the charges levelled at NGOs. The existence of such a link would assume that money from non-Egyptian sources is essentially different from (and more dangerous than) money from Egyptian sources and/or that human rights activists do not possess agency in deciding upon the aims, objectives, activities and strategies of their organizations.
} 
the process of an investigation into the murder of two young men from the village on August $14 .^{52}$ It was not the first time that an Egyptian human rights organization had reported a case of torture in an Egyptian police station. It is widely recognized by human rights advocates that torture has become a systematic part of police investigations in even the most minor of cases. However, what was unique about this case was the large number of people brutalized and the demographic of the village. The village contains approximately 70 percent Coptic Christians—whereas Coptic Christians make up approximately 10 percent of the total population of Egypt. ${ }^{53}$ Both men who were murdered were Copts and almost all the people interrogated and tortured by the police were Copts.

The ‘Coptic question' in Egypt is extremely sensitive. Colonial powers used the question of ethnic and religious minorities in the Arab region as a means of 'divide and rule.' Moreover, Britain, France and Russia claimed jurisdiction over Christian minorities in the region in order to gain a foothold in the control of the Ottoman Empire. The Egyptian nationalist movement, struggling against British colonialism, rejected the notion of Copts as a religious minority in order to unite Egyptians against foreign rule. Until today, it remains extremely difficult to discuss issues pertaining to Coptic Egyptians. The existence of religious discrimination or sectarianism is almost universally denied within Egypteven amongst some Coptic religious figures. ${ }^{54}$ The targeting of Copts in acts of violence is always blamed on Islamist 'terrorists.' Anyone who even tries to suggest that Copts do not enjoy the same rights as Muslims is automatically accused of inciting sectarianism. ${ }^{55}$ The refrain often repeated is that Copts are 'an integral part of the national fabric.'

The EOHR's report did not intend to address the question of the position of Copts within Egypt. Its objective was to report the degree of police brutality. However, it did mention that the police, not wanting to blame the murder of the two Coptic men on Muslims, because of the dangers of creating a picture of sectarian hatred or the continuing existence of Islamist extremists, decided that they had to pin the crime on a Copt. ${ }^{56}$ This admission would later be used to condemn the EOHR for encouraging foreign interference in domestic affairs by providing information that could be used to condemn Egypt for discrimination against Copts.

\footnotetext{
${ }^{52}$ EOHR, The Village of al-Kushah: A Case of Mass Punishment (Cairo: EOHR, September 1998a). ${ }^{53}$ Accurate statistics on the number of Copts in Egypt are not available- some Egyptians believe that official statistics underestimate their numbers.

${ }^{54}$ This is despite the fact that Coptic Egyptians do face some restrictions on their freedom of worship since the law only allows the construction, alteration, or repair of churches by presidential decree.

${ }^{55}$ During the trial, the public prosecution accused Saad Eddin Ibrahim of inciting the sectarian violence that occurred in al-Kushah in January 2000 because of a letter he wrote to an organization overseas, in which he claimed that Egyptian Copts have been discriminated against since the Islamic conquests. alHayat, 18 February 2001, pp. 1, 6.

${ }^{56}$ EOHR, The Village of al-Kushah.
} 
As with all reports, the EOHR distributed copies to its established mailing list—-the local and international press, local and international organizations and the Egyptian government. It also filed complaints with the public prosecutor. However, no response was forthcoming from the authorities and the only local press to report the case was al-Ahali (the weekly newspaper of the leftist Tagammu“ party) and al-Watani (the only newspaper published by and for Copts).

It is significant that the case did not become an issue of national public debate until several weeks later when the British newspaper, The Sunday Telegraph, picked up the story on October 25, 1998. The headline read: “Egyptian police ‘crucify’ and rape Christians-thousands of Copts in Egypt have been nailed to the doors of their homes, beaten and tortured as authorities crack down on non-Muslims”. ${ }^{57}$ The article was grossly exaggerated, bore little resemblance to the EOHR report and was based on sources that were not verified. Undoubtedly, prejudices about the 'Orient' among newspaper staff allowed such a story to be printed without the reporter having set foot in Egypt to verify the facts. The article triggered an angry response from the Egyptian national press, politicians and many elements of civil society. The article was read as the latest attempt by the 'West' to use the issue of religious minorities in the Middle East to exert their control over the region. The Committee for National Security Affairs (a body in the parliament's upper house) issued a statement on October 28 denying, "any discrimination based on religion, sex, or belief” in Egypt. The statement went on to say, "these allegations are not new and it is not the first time that the Western press publishes slanderous claims to tarnish Egypt's image abroad to put pressure on Egypt to take certain political decisions concerning regional issues.”58 In a public show of patriotism, 80 Egyptian Copts filed a case in an Egyptian court demanding \$17 billion in compensation from The Sunday Telegraph for false allegations of persecution of Egyptian Copts. The lawyer representing the litigants stated that The Sunday Telegraph report "aimed at distorting Egypt’s reputation and planting civil strife.” ${ }^{59}$ In addition, the EOHR issued a press release in defense of its report, stating, "The EOHR has not monitored any egregious violations by the security authorities against Coptic Christians because of their religion ... The Copts of Egypt are not a minority but, together with Muslims, make up the fabric of the nation.”60

However, the fact that the EOHR spoke about the incidents in al-Kushah was enough to link the report to the international outcry over the incidents. A weekly, quasi-governmental magazine, Ruz al-Yusif,

\footnotetext{
${ }^{57}$ Christina Lamb, “Egyptian Policy ‘Crucify’ and Rape Christians”, Daily Telegraph, October 25,1998, http://216.247.220.66/archives/foreignpolicy/lamb10-29-98.htm.

${ }^{58}$ al-Hayat, 29 October 1998, p. 5.

59 al-Ahram, 3 November 1998, p. 1.

${ }^{60}$ EOHR, “Press release,” Cairo, 31 October 1998.
} 
published a report blaming the Coptic priest of al-Kushah, the EOHR report and Coptic groups in the United States for inventing stories of religious persecution in al-Kushah. 'Westerners' are always ready to believe these stories, argued the magazine, hence the story in The Sunday Telegraph. ${ }^{61}$ An article with similar conclusions was published by another weekly, quasi-governmental magazine, $\underline{\text { Sabah al- }}$ Khayr, under the title "The Persecution of Copts is the latest in a series of attacks on Egypt," in which various Egyptian intellectuals were interviewed for their response to the case. The EOHR was blamed for putting its report on the internet, where it was used by the international media, such as The Sunday Telegraph, together with international human rights groups. ${ }^{62}$ In addition to new media technologies and the global media, this article mentions the role of emigrant communities of Coptic Egyptians in creating unwelcome international interest in an essentially internal affair. ${ }^{63}$ In other words, cultural processes associated with globalization were perceived to be threatening Egyptian national sovereignty. The media attention on the al-Kushah affair caused sufficient domestic embarrassment for the government to intervene directly in an attempt to discredit the EOHR and undermine its claims by orchestrating an event that would divert attention away from the question of what actually happened in al-Kushah. On November 4 and 5, the three major quasi-governmental daily newspapers (alGumhuriya, al-Ahram and al-Akhbar) all ran stories of how the Suhag branch of the EOHR had resigned over the EOHR report of the events in al-Kushah, describing it as biased and full of lies. The resigning members criticized the EOHR head office for not seeking the input of the Suhag branch in compiling the report and for using impartial sources. ${ }^{64}$

The stakes against the EOHR were raised even higher when quasi-governmental daily al-Misa' of 6 November ran a front-page story on the resignations with new reasons: that "the EOHR head office is working for the West," that "a foreign correspondent had secretly accompanied the fact-finding mission," and that "the mission met with terrorists." The allegations of foreign and terrorist links were meant to immediately discredit the EOHR and characterize its report as being directed against Egypt's interests. The ex-Suhag branch members "opposed the report, which is being used to attack national security,” and accused the EOHR head office of being "unpatriotic.” They planned to establish an alternative human rights group that "would rely on national and not foreign funding [like the EOHR]." 65

\footnotetext{
${ }^{61}$ Ruz al-Yusif, 2 November 1998, pp. 19-24.

${ }^{62}$ Sabah al-Khayr, 5 November 1998, p. 4.

${ }^{63}$ Ibid, pp. 3-7.

${ }^{64}$ al-Gumhuriya, 4 November 1998, p. 3; al-Ahram, 5 November 1998, p. 1; al-Akhbar, 5 November 1998, p. 8.

${ }^{65}$ al-Misa', 6 November 1998, p. 1.
} 
However, it was not only those opposing the EOHR report that attempted to link accusations of religious persecution with attempts to threaten national interests. Ayman Nur, an EOHR board member and member of parliament for the liberal Wafd party, wrote a response to a letter from Lord David Alton of the British House of Lords to the governor of Suhag, in which the former warned that the religious persecution of Copts in al-Kushah could “cost Egypt tourists.” Ayman Nur opposed the apparent attempt by Lord Alton to “intervene in Egyptian internal affairs," asserting that "it is not true that there are sectarian, religious or political reasons for the events in al-Kushah.” Nur accused Alton of threatening Egypt's tourist industry, “as terrorists have threatened Egypt's tourist industry and hence its economy, for political reasons.”66

The next person to demonstrate his patriotism was Pope Shanuda, head of the Orthodox Coptic Church in Egypt, in a statement published in al-Hayat, on November 7, in which he denied the reports by the Western media that Copts in al-Kushah had been persecuted and stated that these reports "tarnish Egypt's reputation, which is unacceptable.” “The Copts of Egypt do not accept foreign intervention in national affairs, which should be resolved peacefully with our officials.” The Pope reiterated that what had happened in al-Kushah was “an ordinary crime of murder with absolutely no link to sectarianism.”67

An attempt was made by Egyptian human rights groups to turn the focus away from patriotic slogans and back to the incidents of torture and the need for the perpetrators to be brought to justice. In a press release, on November 10, seven Egyptian human rights organizations called on the president to bring to justice those officials responsible in al-Kushah and to make an official apology to and financially compensate the people of al-Kushah for the harm they had suffered. ${ }^{68}$ In response, in his address to parliament at the beginning of his new presidential term, Husni Mubarak strongly implied that any attempt to publicly address the events in al-Kushah would be considered a direct provocation of sectarianism and, moreover, would be playing into the hands of external powers, including Israel (which is widely regarded in Egypt with deep suspicion and even hatred). He criticized those who "provoke conflicts between Copts and Muslims in Egypt as a means of attempting to influence Egyptian decision-making,” including “the Israeli prime minister’s office [who] published on the internet these claims [of persecution of Copts in Egypt].” He also expressed his sorrow that, "there are a few elements within Egypt that focus on this subject and want a special meeting with me because of it ... I am a president for all Egyptians and I meet them as Egyptian citizens, far away from

\footnotetext{
${ }^{66}$ al-Wafd, 7 November 1998, pp. 1-2.

${ }^{67}$ al-Hayat, 7 November 1998, p. 5.

${ }^{68}$ Seven Egyptian human rights groups, “Press release,” Cairo, 10 November 1998.
} 
sectarianism. We are all working under Egypt's flag and constitution, which guarantees to all Egyptians rights and obligations without discrimination and despite their beliefs.”69

Despite the fact that the government admitted that "police excesses" had taken place in al-Kushah, ${ }^{70}$ the campaign against the EOHR and its report continued. The next day, Akhbar al-Hawadith, a quasigovernmental weekly newspaper that reports crimes, ran a front-page story about the resignation of the Suhag members, their objection to the report and the EOHR's links to foreign organizations. In addition to foreign links and foreign funding, this article suggested 'bribery' as an element behind the writing of the EOHR report. The headline stated: "The revelation of the hidden truth in the al-Kushah events: foreign funding, films, gifts and grants in return for tarnishing Egypt.” The article reported that the Suhag members had found evidence linking the EOHR to bribes from foreign organizations whose purpose was to harm Egypt. According to one of the ex-members, 'Ismat Muhammad Ahmad, "these organizations [human rights organizations] have become a dangerous phenomenon that must be challenged given the harm caused to Egypt and their cooperation with Egypt’s enemies ... .,71

This front-page news item encapsulated the two elements that were systematically used thereon in all newspapers to discredit the EOHR, its report and human rights work in general. The first and most important element is the acceptance of foreign funding and having links with the 'West' as an act of national betrayal. Once such links are established, then it necessarily follows that individuals within these organizations are corrupt (both morally and financially). The second element is that the issue of foreign funding and links with the West becomes of much greater significance than the original incident—-that is, police abuse of innocent civilians.

Reinforcing the campaign to discredit the EOHR report, Mustafa Bakri, publisher of the independent weekly newspaper al-Usbu“ and his brother Mahmud Bakri resigned from the EOHR, "in protest of the lies published by the EOHR, claiming that Copts in al-Kushah were severely tortured, which has harmed Egypt and its reputation abroad.,72 Mustafa Bakri had previously been an elected member of the EOHR board.

The stakes against the EOHR were further raised on November 23, when al-Usbu' printed on its first page a picture of a check made out to the EOHR for $\$ 25,000$ from the British embassy and above it was written: “The Price of Treason: A Foreign Embassy Pays Egyptians for a Fabricated Report about the Persecution of Copts in al-Kushah.”

69 al-Hayat, 11 November 1998, p. 6.

${ }^{70}$ A statement by 'Usama al-Baz, presidential advisor, reported in al-Ahrar, 11 November 1998, p. 3.

${ }^{71}$ Akhbar al-Hawadith, 12 November 1998, p. 1.

${ }^{72}$ al-Usbu', 16 November 1998, p.1. 
The article continues:

In the latest attempt to harm Egyptian national security, the embassy of a foreign country in Cairo gave a check to the EOHR for $\$ 25,703$ for writing a fabricated report claiming the existence of religious persecution of Copts in al-Kushah ... This check reveals the collaboration of the EOHR with other elements to tarnish Egypt's reputation and the supply of funds by the embassy of a foreign country for a fabricated report that can be used by the Western media to harm Egypt's national security and interests. al-Usbu“ is presenting these facts to the public prosecutor to defend the nation's security, which we cannot allow to be subject to the games of a handful of collaborators with the West and their intelligence agencies. $^{73}$

The quasi-governmental press quickly picked up on al-Usbu's story, publishing the news of Mustafa Bakri's statements to the public prosecutor on their crime pages. ${ }^{74}$

The whole affair shocked the EOHR board, which convened an emergency meeting to discuss the issue, following which, a statement was issued in which it was asserted that there was no link between the British embassy check and the al-Kushah report. The money was the second installment toward a legal aid project for women and people with disabilities. The board decided to return the British embassy check, to stop accepting funds from any foreign government or embassy and to review the acceptance of funds from any other foreign organization in future. This story was widely published in the Egyptian national press. ${ }^{75}$ The actions of the EOHR board in returning the check and refusing future funding from foreign governmental bodies only helped to provide ammunition to attack the EOHR further. In an interview with the English language weekly the Cairo Times, Bakri claimed that the fact that the EOHR board had returned the check was proof of a connection between the check and the al-Kushah report. ${ }^{76}$

The following days witnessed a media focus on the issue of foreign funding of the EOHR to the exclusion of any discussion about the events in al-Kushah. ${ }^{77}$ Some of the articles were sympathetic to

\footnotetext{
${ }^{73}$ Ibid, p. 1.

${ }^{74}$ See al-Ahram, 25 November 1998, p. 22; al-Ahram, 26 November 1998, p. 28; and al-Gumhuriya, 26 November 1998, p. 13.

${ }^{75}$ See, al-Ahram, 28 November 1998, p. 18; al-Gumhuriya, 28 November 1998, p. 1 of the quasigovernmental press and al-Hayat, 28 November 1998, p. 5; al-Wafd, 29 November 1998, p. 2 from the non-governmental press.

${ }^{76}$ Cairo Times, 1-15 December 1998, p. 6.

${ }^{77}$ See articles in al-Wafd, 30 November 1998, pp. 2, 5, 8; al-Hayat, 30 November 1998, p. 5; al-Usbu‘, 30 November 1998, pp. 1, 3, 4, 18.
} 


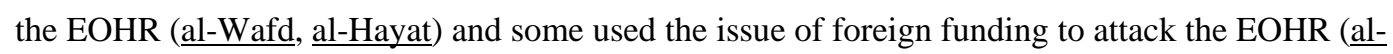
Usbu'), however, all articles had accepted the parameters of the debate as those of 'national security' and 'national interests'. It was no longer important whether Egyptian citizens had been tortured by the police. What was important was whether Egypt's 'national security' had in any way been compromised by the EOHR.

The general consensus constructed through the press over the accusations targeted at the EOHR created a suitable climate for the public prosecutor to investigate the accusations made by Mustafa Bakri and arrest EOHR Secretary General Hafiz Abu Sa‘da (on December 1). The official investigation was incorporated into, and became an extension of the process of the political 'Othering' of human rights NGOs. The investigations into the check and its link to al-Kushah were extensively leaked to the press with the effect that Abu Sa'da was proclaimed guilty by many without even being formally charged. The accusations made by the prosecutor included: "accepting bribes from a foreign country with the aim of harming the national interest and spreading false allegations and rumors in order to disturb public security and peace” and "receiving donations without a license." ${ }^{\text {78 }}$ In addition, press reports, particularly in the government press, implied financial corruption by referring to the relatively large sums of money received by the EOHR. ${ }^{79}$ The political party opposition press did little to defend Abu Sa'da against these accusations (although some individual writers wrote in defense of the EOHR). In response to Abu Sa'da’s arrest, eight other Egyptian human rights organizations held a press conference in which they condemned the "political campaign against the human rights movement under the cloak of a legal case.”80 The EOHR board took the symbolic decision of freezing the organization's activities to protest the anti-democratic atmosphere that made it impossible for the EOHR to conduct its work. ${ }^{81}$ The British embassy issued a public statement denying that the check was in any way linked to the al-Kushah report and asserting that it was intended for a legal aid project. ${ }^{82}$ The arrest of Abu Sa'da also met with a strong campaign by international human rights organizations calling for his release.

Reports in the government press of the continuing investigations were unable to produce any new accusations and the focus stayed on the issue of money—-from where, how much and in which bank

\footnotetext{
${ }^{78}$ al-Ahram, 2 December 1998, pp. 1, 22; al-Akhbar, 2 December 1998, p. 1; al-Gumhuriya, 2 December 1998, p. 1; al-Wafd, 2 December 1998, p. 1.

${ }^{79}$ See al-Ahram, 2 December 1998, p. 22.

${ }^{80}$ al-Hayat, 3 December 1998, p. 5.

${ }^{81} \underline{\text { al-Wafd, }} 4$ December 1998, pp. 1, 5; al-Hayat, 4 December 1998, p. 5; al-Sha‘b, 4 December 1998, pp. $1,8$.

${ }^{82}$ al-Akhbar, 4 December 1998, p. 8; al-Ahrar, 4 December 1998, p. 1; al-Hayat, 4 December 1998, p. 5.
} 
account it was deposited. ${ }^{83}$ By December 12, 1998, Abu Sa'da was released on bail—in time to attend the celebrations in Paris of, ironically, the fiftieth anniversary of the Universal Declaration of Human Rights. However, the debate was by no means over and many newspaper column inches continued to be dedicated to the issue of human rights organizations and their foreign links, including those written by major writers and journalists from across the political/ideological spectrum. ${ }^{84}$

The EOHR al-Kushah report had managed to elevate the issue of foreign funding of NGOs to a priority issue of national security. Whilst the issue remained within these parameters the government was not challenged on its human rights record in any way. During the debates that surrounded the EOHR report on al-Kushah, there was a general failure to deconstruct the 'national security' argument. This made it easy for the authorities to reopen the case against Abu Sa'da in February 2000, a few weeks after violence between Copts and Muslims broke out in al-Kushah on January 1, 2000, resulting in the deaths of 20 and the injury of 33 people, in addition to the destruction and damage of property. ${ }^{85}$ This time, Abu Sa'da was charged with receiving funds without official permission according to a 1992 military decree, which carries penalties of a maximum sentence of 15 years imprisonment. ${ }^{86}$

\section{Conclusion}

The reactions to the EOHR report on the incidents in al-Kushah illustrate the political effects of the struggle over the reproduction of national identity. This contestation occurred principally within civil society, via the media. The allegations of police brutality in al-Kushah were glossed over with slogans of 'national unity' and transformed into a debate about the threat of human rights NGOs to the nation. The government and some elements of civil society sought to discredit the report, the EOHR and human rights NGOs in general because of their links with organizations in the West, particularly through their receiving of grants from these organizations. In order to protect the nation from Western intervention in domestic affairs and guard Egyptian national sovereignty, it was deemed justifiable to harass human rights activists on the basis of their links with the West. In this way, contestations over Egyptian national identity resulted in the further narrowing of the public space available for independent political action and criticism of the government.

\footnotetext{
83 al-Ahram, 5 December 1998, p. 18.

${ }^{84}$ For example, Islamist writer Fahmi Huwaydi, al-Ahram, 8 December 1998, p. 11; liberal Wahid 'Abd al-Magid, al-Wafd, 8 December 1998, p. 7; pro-government Sa'id Sunbul, al-Akhbar, 9 December 1998, p. 3; and leftist Rifa‘t al-Sa‘id, al-Ahali, 9 December 1998, p. 9.

${ }^{85}$ EOHR, "A Summary of the Results of the Fact-Finding Mission on the Events in al-Kushah, Suhag," Cairo, February 2000.

${ }^{86}$ Abu Sa'da was never brought to trial but, as of writing, the charges had not been dropped.
} 
Positions in the debate over the EOHR report on al-Kushah, the British embassy check and the detention of the EOHR secretary-general cut across political party and ideological lines, rendering it impossible to attribute certain positions to any particular political/ideological trend. The lines of the debate by no means reflected the boundaries between government and non-governmental individuals and bodies. A significant section within civil society lined up against the EOHR, demonstrating the degree to which hegemony works. Moreover, the refrain that 'Copts make up the fabric of the nation' was consistently repeated by all participants in the debate, including the EOHR and Coptic individuals themselves. Even if this refrain is not widely believed, its constant repetition like a mantra, produced the effect of compliance and made it impossible to question the dangers of imposing national unity to the detriment of basic human rights. ${ }^{87}$

In the course of the debates over the series of events linked to the EOHR report, the binary division of 'Occident' and 'Orient' was continually reproduced and the interests of the 'West' were represented as being diametrically opposed to those of Egypt. The hegemonic representations of the Egyptian nation and the 'West' as two homogenous and diametrically opposed entities operate to delegitimize the work of human rights NGOs, which transgresses notions of the national. Consequently, it is necessary to deconstruct binary representations of Egypt/the 'West' by stressing the heterogeneity of both the 'West' and Egypt. The failure to deconstruct this binary division signifies a failure to challenge the moral-ideological justification for the harassment of human rights NGOs and the denial of human rights of Egyptian citizens. ${ }^{88}$ Without challenging hegemonic cultural representations of Egypt, suppression of human rights organizations and their work is deemed justifiable. It is not only human rights activists who are the victims of harassment. The human rights of all are also threatened.

Above I have argued for a conceptualization of culture as a fluid and historically contingent process and demonstrated how this process plays out in the context of postcolonial Egypt. Yet, those that engage with the realm of culture as a means of deploying power (whether to uphold or challenge the political status), more often than not resort to a representation of national or group identities as essentialized and immutable. In other words, cultures and identities are socially constructed, yet, for political reasons, they are represented as natural and unchanging — what Spivak has termed 'strategic essentialism' ${ }^{89}$ Of particular interest here, is how the reproduction of national culture and identity acts

\footnotetext{
${ }^{87}$ With regard to the way that official rhetoric produces political compliance in Syria, see Wedeen, Ambiguities of Domination.

${ }^{88}$ Some members of civil society have publicly opposed the essentialized representation of the 'West' (for example, Husayn 'Abd al-Raziq, in the English language weekly newspaper, al-Ahram Weekly, 21-28 January 1999, clearly argues against seeing the 'West' as a “single, monolithic entity”). However, there is currently no systematic attempt in the Arabic media to make this central to arguments defending the permissibility of Egyptian NGOs receiving foreign grants.

${ }^{89}$ Gayatri Spivak, In Other Worlds: Essays in Cultural Politics (New York: Methuen, 1987).
} 
as a means of reproducing the dominant configuration of relations of power in society, or hegemony. Democratization is not only about allowing multi-party elections or enabling the independence of the judiciary, but also about reconfiguring relations of power in order to open spaces for pluralism, diversity and inclusiveness. This necessarily entails challenging monolithic representations of national culture that impose unity to the detriment of the rights of individual citizens.

9, 304 words. 